\title{
"Not all spaces are territories": creating other possible urban worlds in and from Latin America - an interview with Raúl Zibechi
}

\author{
Monika Streule $^{1}$ and Anke Schwarz ${ }^{2}$ \\ ${ }^{1}$ Department of Architecture, ETH Zurich, Zurich, Switzerland \\ ${ }^{2}$ Institute of Geography, TU Dresden, Dresden, Germany \\ Correspondence: Monika Streule (streule@arch.ethz.ch)
}

Received: 16 October 2018 - Revised: 12 March 2019 - Accepted: 13 March 2019 - Published: 26 March 2019

\begin{abstract}
In light of his most prominent book "Territories in Resistance" (Zibechi, 2008), we conducted an interview with the researcher, journalist, and activist Raúl Zibechi. A well-known Uruguayan columnist with various Latin American newspapers, Zibechi was introduced to an English-speaking audience when translations of two of his books were published in 2010 and 2012 (Zibechi, 2010, 2012a). Combining activism and research, he has been working with social movements throughout Latin America since the 1980s. Socioterritorial movements, the key concept around which much of Zibechi's work revolves, are of particular interest for our theme issue "Contested Urban Territories: Decolonized Perspectives". Our interview revisits Zibechi's idea of the emergence of new or other subjects through socioterritorial practices, and in consequence, of socioterritorial movements as harbingers of possible urban futures. In this context, the interview also explores links to the writings of Carlos Walter Porto Gonçalves on "territory", Henri Lefebvre on "space", and Frantz Fanon on "zones of being and non-being". We understand a conversation along these lines as a contribution to the ongoing debate on a decolonialization of knowledge and knowledge production in the field of urban studies.
\end{abstract}

\section{Introduction}

In light of his most prominent book "Territories in Resistance" (Zibechi, 2008), we conducted an interview with the researcher, journalist, and activist Raúl Zibechi. A wellknown Uruguayan columnist with various Latin American newspapers, Zibechi was introduced to an English-speaking audience when translations of two of his books were published in 2010 and 2012. Combining activism and research, he has been collaborating with social movements throughout Latin America since the 1980s. This provides him with an extraordinarily rich empirical context for critical thought. Socioterritorial movements, the key concept around which much of Zibechi's work revolves, are of particular interest for the present theme issue "Contested Urban Territories: Decolonized Perspectives". We structured the interview around four core contributions of Raúl Zibechi's work, accordingly organizing the present paper into four sections. In the first section, "Urban territories of resistance", we address current struggles and contestations over urban territories in Latin America - such as organizations inheriting the mantle of the unemployed workers' movement in Argentina and speak about their long-term interventions in urban peripheries, building up different ways of communal everyday life in cities such as Buenos Aires or Córdoba. The second section, "New subjects, new territories", revisits Zibechi's idea of the emergence of new or other subjects through socioterritorial practices and, in consequence, of socioterritorial movements as harbingers of possible urban futures. Zibechi gives concrete examples of how collective acts of urban subjects from below and from the periphery may create such different urban worlds. At the same time, he points out the fragility of such territories of poverty. The third section draws on a decolonial perspective to problematize neocolonial practices of natural and social resource extractivism, discussing possible links between such extractive geographies and the urban context. Finally, the fourth section reflects on collective ways of knowledge production, understanding more dialog- 
ical research strategies as a major current task for societies in transition. Here, Zibechi refers to a number of indigenous and nonindigenous scholars, introducing, for instance, Silvia Rivera Cusicanqui's collaborative research projects in the Aymara highlands of Bolivia. The interview closes by examining how a relational notion of territory may open up new grounds for critical urban research more in general.

In this interview, Raúl Zibechi offers an open conceptualization of territory that is focused on societies in movement and their social subjects, relating them to processes of territorialization. Territorialization is understood as a social practice encompassing much more than merely an appropriation of urban land. It includes the implementation of different social ties and more horizontal structures, thus enabling a variety of ways to create other possible urban worlds in and from Latin America. Therefore, this contribution exemplifies the interface between academic research and social movements. It showcases the tensions and contradictions we may encounter in the multitude of voices on the idea of urban territories - representing simultaneously a useful tool for social struggles and an analytical concept in the academic discourse. With respect to the latter, the interview also explores links to the writings of Carlos Walter Porto Gonçalves on "territory", Henri Lefebvre on "space", and Frantz Fanon on "zones of being and non-being". We understand a conversation along these lines as a contribution to the ongoing debate on a decolonialization of knowledge and knowledge production in the field of urban studies. Adopting a decolonial perspective on contested urban territory hence implies acknowledging urban theory as being both provisional and open to revision.

As theme issue coordinators and interviewers, we believe this conversation with Zibechi complements the assembled papers in that it provides a specific facet of this kaleidoscope of socioterritorial thought. The interview provides further reflections on the concept of urban territories and offers fresh insights into current territorial practices and urban contestations from a Latin American perspective. Beyond their specificity, these inspiring examples of socioterritorial practices add a comparative perspective to urban experiences elsewhere. As such, we see this interview as an important contribution to a multilingual debate about contested urban territories that embraces decolonized perspectives. We conducted the interview with Raúl Zibechi in written form between December 2017 and August 2018 - and thus just a few months prior to the October 2018 presidential elections in Brazil. In light of the current rise of populist right-wing governments not only in Brazil but from Guatemala and Honduras to Colombia and Argentina, and their increasingly repressive stance towards social movements and environmental protections, as well as indigenous and women's rights, these thoughts have undoubtedly gained added weight.

\section{Urban territories of resistance}

Monika Streule and Anke Schwarz: In an article published in the Mexican newspaper La Jornada (Zibechi, 2017b), you wrote that two decades after the start of struggles of the piqueteros - the picketers most often associated with the militants of the unemployed workers' unions who arose after the mid-1990s in Argentina and played a key role in the events of 2001 - it seems to be the right time to evaluate what is left and what has vanished of that promising experience when the unemployed occupied the center of Argentina's political stage. Today, where would you locate current urban struggles in Latin America? Who are the protagonists of such urban socioterritorial movements? What are their aims and strategies?

Raúl Zibechi: The piquetero movement took two contradictory paths. On the one hand, the movement dispersed, was coopted, or became disorganized, and very little was left standing from those organizing experiences. There are $p i$ quetero groups that have no autonomy and are subordinate to the state or political parties. On the other hand, an important sector of society was transformed, giving rise to hundreds of different initiatives, such as social centers, cultural centers, and even a trade union, the Confederación de Trabajadores de la Economía Popular, which brings together dozens of cooperatives and collectives that work in what has been called the informal sector. This is very important because it tells us that the piquetero experience was not in vain. In addition, we have to recognize the almost 400 reappropriated factories (fábricas recuperadas) that sprang to life during the same time and have not stopped growing, as well as hundreds of independent high schools (bachilleratos populares) that were established in piquetero territories and in reappropriated spaces. We also have to acknowledge the self-managed cultural magazines, some 200 of which formed the Asociación de Revistas Culturales Independientes de Argentina (AReCIA). They reach 7 million readers, covering political, cultural, and social topics; some have large print runs, such as Barcelona, and others publish just a few hundred copies, and there are very interesting websites such as La Tinta in Córdoba, Argentina. These media are created and maintained by social collectives that do not depend on either the market or the state and are closely tied to social movements. If, for example, we want to know what is happening with the resistance to mining or the conflict with Monsanto in the city of Córdoba, these magazines are the only source of information. These experiences show us that an important sector of society is creating new worlds (see, e.g., Zibechi, 2017a).

M. S. and A. S.: Has this transformation of urban movements over the past few years led to an institutionalization of their structures and struggles?

R. Z.: I do not see it that way. On the one hand, there are movements that do become institutionalized, and even in these cases, it is not through the customary way of becoming institutions, but rather informally, connected to the government's social policies. But the main tendency is to be firmly 
grounded in collective experiences. So we have hundreds and thousands of cultural and social centers, media, factories, and collectives that struggle against gender-based violence and more. They work independently and autonomously. These organizations and movements are disputing territories with capital and the state. We should also mention the artists' initiatives and the women's movement, which is very strong in Argentina today. In the past 3 years, their annual meetings have been attended by more than 70000 women. In terms of strategies, they seek to build new worlds, spaces, and territories where the collective subjects decide and carry out their lives, or at least an important part of their lives, and participate decisively in production. Production is a new element introduced by the piquetero movement. Up until then, the urban poor did not produce; they picked up the crumbs that the rich tossed away. Now there is a lot of production, including of food, thanks to a strong rural-urban alliance that necessarily involves the urban peripheries, in other words, the territories of poverty.

M. S. and A. S.: We believe that such rural-urban alliances are quite relevant for a better grasp of the territorial contestations this Geographica Helvetica theme issue is all about. Could you go more into detail?

R. Z.: A good example are the health brigades organized by the Medical College in Rosario, Argentina. Before finishing their studies, medical students are required to spend a week in a town of fewer than 10000 inhabitants, usually surrounded by soy plantations. With approval of the municipality, the students do an epidemiological study of the population and they later debrief residents in a large assembly meeting. That is how they found out that cancer rates in these towns are 5 to 7 times higher than the national average. These findings also encourage collectives to organize in the towns, in collaborations with doctors, something that would be very difficult if such collaborations did not exist. At the same time, I do not doubt that there are mafias in these urban peripheries, especially the police colluding with drug traffickers to cover up femicides. In these territories of poverty, we have a triple alliance between the state, narcos, and murderers of women, which has become an undisguised way of controlling young people and especially poor, black, and mestiza women. This alliance is the main challenge for the survival of grassroots movements and organizations.

M. S. and A. S.: That is particularly true for women and for the urban poor. Let us, for instance, remember the femicides and gender-based violence occurring on the outskirts of Mexico City. The situation is so bad that in 2015, the municipality of Ecatepec, in the State of Mexico, issued a "gender alert" due to the extremely high number of murdered and disappeared women. In Brazil, there has been an increase in extreme violence against women, too. We recall the March 2018 murder of feminist Rio de Janeiro city councilor Marielle Franco. As a prominent Afro-Brazilian gay and human rights' activist, she was particularly committed to the cause of black women, the LGBTI community, and residents of favelas. How is this act of violence being processed in the communities and urban movements in Brazil?

R. Z.: While I do not live in Brazil, I think there are two aspects here: first, the violence against the black population living in favelas, which grows exponentially each year. In 2017, a record was set with 63000 violent deaths, which places Brazil among the 10 most violent countries of the world in terms of population density. Further, 8 of those 10 countries are located in Latin America. Inequality is the cause of violence, and this is one of the most unequal regions in the world. In other words, Brazil's black, impoverished, and youth population is suffering atrocious violence, every single day of the year and in all of the spaces of their lives. The murder of Marielle Franco is part of that violence. But, second, it carries an additional message: "Black men and black women, do not organize and do not struggle because we are going to kill you." It is the same message the $\mathrm{Ku}$ Klux Klan supported in the United States during the 1950s and 1960s. Why now? Since 2013, the black population in Brazil has organized itself without the state or political parties. Even within trade unions, black workers, male and female, have led the main struggles of the past few years. In the favelas, there is a strong drive to establish new organizations, the most notable of which are those led by black, feminist women. Here there has been a phenomenal change, and this is the message behind the murder of Franco.

M.S. and A. S.: In your 2008 book Territorios en resistencia. Cartografía política de las periferias latinoamericanas (Territories in Resistance. A Cartography of Latin American Social Movements; Zibechi, 2012a), you write that it is practically impossible to find such territories in resistance in the "Global North". Could you explain why?

R. Z.: I would not say the same thing today. In the past 3 years, I have traveled to Spain, Italy, and Greece, and I found collective vegetable gardens in urban peripheries, reappropriated spaces, factories, and a new type of relationships, made possible by the crisis and a new mode of capital accumulation that is excluding young people with a lower socioeconomic status. In Greece, young people can aspire to a monthly salary of no more than EUR 500. When I wrote the book you mention, there was none of this, and what prevailed was a colonization of all urban environments by capital, coupled with very strong real-estate speculation, which made it almost impossible to open up cracks for some alternative in those spaces.

M. S. and A. S.: Do you see a glimpse of hope for any form of territories of resistance somewhere else in presentday Europe?

R. Z.: My feeling is that if no important crisis occurs, like the one that shook Europe from 2010 onwards, there is not the least chance for change. One of the most interesting experiences I have seen is Azienda Mondeggi, close to Florence in Italy, a farm reappropriated by young people, who are practicing agriculture, recovering several hectares as a commons, and establishing alliances with other grassroots organiza- 
tions. In Rome, there is the resistance to gentrification in the Pigneto neighborhood. In the Basque city of Vitoria-Gasteiz, the entire neighborhood of Errekaleor has been recuperated. There, young people have organized a struggle against realestate speculation, and there are dozens of urban gardens. My impression is that the crisis and the change in the modes of capital accumulation - with predominance of financial capital - have meant that the movement has also changed course. There are many activists who do not depend on the state for anything and are now working to build something new and different. This is a new strategy: historically, social movements have had a strong relationship with both the state and capital, which consisted of opposition and resistance but also in demands. Movements today follow a dual strategy: they resist and demand, but they also build. Made popular by both the piqueteros in the cities and the landless in Brazil, as well as the indigenous people who have always used it, this mode of operation places us in a different relationship vis-à-vis the European movements. Before, we Latin American activists used to go to Europe to ask for solidarity; now we are interacting and learning from one another. In Spain, every year there is a school for social movements with the participation of a grassroots confederation of 300 ecological groups called Ecologistas en Acción, the Confederación General de Trabajo (CGT) trade union, and Baladre, which coordinates struggles against unemployment, impoverishment and social exclusion. These three organizations work on urban issues and have collaborated for a number of years. The school is very similar to the ones we have in Latin America, and we clearly share much in common. I was able to find similarities in Italy and Greece in the initiatives at the grassroots level.

\section{New subjects, new territories}

M. S. and A. S.: Contestations over urban territories are not only struggles over the production of urban space but always also about a renegotiation and possible reconfiguration of unequal relations of power. We are particularly interested in the dialectics of subject formation and the making of territories. Are new or other subjects - or as you put it, "subjects who embody other social relations" (Zibechi, 2007) - always creative of new territorialities, and how? Is re-territorialization habitually a moment of empowerment?

R. Z.: Not always, but the tendency is to create new territories. This is not solely a rational matter, although there is a rationale that explains it that could be similar to that found in women's groups. Why do women create groups in which only women can participate? Because they need spaces of trust, where they can breathe and be who they are, without having male surveillance, in a manner of speaking. Territories play a similar role. Nobody would state "let us create territories to set ourselves free". Undeniably, half of the Latin American population has no effective rights, nor education, quality healthcare, housing, or access to the city. In Brazil, the poor are excluded from the city because every day they have to pay two bus fares going and two coming back, which is almost equivalent to half a minimum salary. Given this exclusion, the poor need to open territories in the cities.

M. S. and A. S.: An increase in public-transportation fares in 2016 was the spark that led to widespread demonstrations in São Paulo and Rio de Janeiro. Could you elaborate a bit more about these protests, the police repression, and how you see these disturbances in the context of contested urban territories?

R. Z.: Following the trajectory of the new urban movements in Brazil, the massive demonstrations in 2016 were not surprising. The attention, certainly, draws towards the massiveness and duration of the protests and the radicalism of many protesters but not the certainty of the complaints and claims. People protested against the increase in transport costs, against the FIFA Confederations Cup in 2013, and against urban redevelopment in the wake of the Summer Olympics in 2016. Right now, there is a mass occupation of derelict land by the homeless people's movement Povo Sem Medo in São Bernardo do Campo, São Paulo, by 30000 people, 8000 families. It started in September 2017 as something small, to demand housing, and, months later, it had become huge and continued to grow. Law enforcement refused to let Caetano Veloso, the most popular musician in Brazil, give a concert in support of the occupiers. This is crazy, but that is how things work here. The movement stemmed from pure necessity; there was no planning because, in fact, the leaders themselves were overwhelmed by their constituents. In Latin America today, the collective subjects living in poverty need to empower themselves through territories where they can build their lives: first housing, then collective spaces for health and education, thus creating new "cities" based on social relationships that they embody in their daily lives.

M. S. and A. S.: In your 2008 book, you distinguish between "territories in resistance" and "territories of emancipation". How do they differ? Are they produced by different types of subjects?

R. Z.: It is a bit of an artificial distinction. Territories in resistance are the elemental spaces that subjects open up to be able to live, like what is happening with the abovementioned Povo Sem Medo land occupation. In reference to the prominent rural landless workers' movement Movimento dos Trabalhadores Sem Terra (MST), it has also been called the "homeless workers' movement". Its activists take over spaces and transform them into territories in resistance. However, not all spaces are territories. There is a difference here. Lefebvre (1974) discusses spaces that are places where we meet and get together to do something specific; so a city is full of spaces. Territory is a concept that originated with the indigenous and peasant movements - the concepts have different backgrounds. For example, when a subject transforms rural space into a territory, that is because the subject conducts his/her life there - housing, work, and education - people's entire lives take place in the territory, and that is 
why it is no longer a space. Territories are potentially places where subjects can emancipate themselves but not necessarily. Territories of emancipation occur when subjects create a new world, where production no longer is done with agrochemicals, and where they decide what type of schools or health they want, where they have power mechanisms different from the state, in other words, non-state powers, powers inspired through a community approach. It is important to distinguish that not all movements seek to create different ways of living in their territories, what some call alternatives and noncapitalist, with other social relationships. Many resist but also reproduce capitalism. The Zapatistas are a good counterexample. With their autonomous municipalities and Juntas de Buen Gobierno (good government councils) they are building a world truly different from the hegemonic one.

\section{Extractive geographies}

M. S. and A. S.: Over the last decade, we have witnessed an accelerated form of neocolonial extractivism in many former colonies in Latin America, Africa, and elsewhere. With regard to natural and social resources, this violent extractive model produces devastated territories through mining, fracking, the construction of hydroelectrical dams, industrial agriculture, and lumbering, etc. These ongoing transformations seem to be the main domain in which scholars fruitfully apply the concept of territory today. According to Svampa and Viale (2014), this extractive model also applies to an "urban extractivism" producing exclusive urban territories. In recent articles published in La Jornada (Zibechi, 2013, 2017b), you engage with these issues. How are such extractive geographies linked to the urban context? How does the concept of territory help in thinking about these linkages?

R. Z.: We have made an error by believing, at least in the early years, that extractivism is an economic model. David Harvey's concept of accumulation by dispossession is very interesting, but we should not become fixated on the economic aspect. I prefer to speak of an extractive society because extractivism covers all aspects of society. If we focus on culture, we see that there is a shift from the central concept of work to the concept of leisure and consumption. This is functional to extractivism because it is a form of accumulation based on dispossession, not on productive work as was the case during the welfare era. We can also observe extractivism in cities - or rather urban speculation, which, as Viale (2017) noted, we should call urban extractivism. We do not just encounter this model in rural areas; it also has a strong urban presence. In Brazil, this was evident in the period leading up to the football World Cup and the Olympic Games in 2014/2016, when 250000 families were displaced from their neighborhoods and homes in order to build urban megaprojects for these events.
In the cities, we see an increasing territorialization by capital that discriminates and creates standardized territories like shopping malls and gated communities, where the poor are excluded. In contrast, the poor create their own territories. We are heading toward segmented cities where the lower social classes and people of color live apart from the rest of society, sometimes separated by real walls and other times by virtual ones. Since 2007, a yearly marcha de la gorra ("march of the caps") takes place in the city of Córdoba, Argentina, as impoverished young people who wear baseball caps are systematically refused entry to the city center and detained by the police. The march is an answer to the daily classist repression that forces impoverished young people to remain in their neighborhoods.

M. S. and A. S.: Is it useful to further expand the concept of extractivism and to apply it to other realms such as knowledge production?

R. Z.: Without doubt. As mentioned by Grosfoguel (2016) and others, there is an academic extractivism. It is very interesting that we can think about the concept of extractivism in the most diverse settings, from knowledge to culture. In this regard I would like to evoke Frantz Fanon's concept of "zones of being and non-being" (Fanon, 1952) - geographies where people's rights are respected and violence is exceptional and other geographies where social relationships are made and conflicts are solved in a violent manner.

M. S. and A. S.: How are Fanon's "zones of being and non-being" related to the concept of urban territories?

R. Z.: It is important to revisit Fanon because on our continent, poverty is black, indigenous, and mestizo. Extractivism behaves differently in the zones of non-being, in a much more violent, more authoritarian way. This is true to such an extent that the Zapatistas define the current model as a "fourth world war". It is, in other words, a war of dispossession if we view it from "below". When Harvey gives concrete examples of accumulation by dispossession, he mentions privatization and patents. While I believe they are valid examples, they operate in the zone of being. In barrios such as favelas or in indigenous communities (prototypical urban zones of non-being), dispossession manifests itself in outrageous violence because the people who live there are different; from the standpoint of capital they are the throwaway sectors of our society.

\section{The conceptualization of territory and critical geography}

M. S. and A. S.: As you emphasized in your writings, the emergence of territory as a scientific concept is strongly embedded in a Latin American political, social, and historical context (see, e.g., Zibechi, 2012b). In other words, we can read this currently applied and discussed notion of territory as a response to the struggles over land (e.g., by the Mapuche, the Guarani-Kaiowá, or the MST) and work (e.g., by the 
piquetero movement), as well as over healthcare and housing (e.g., by the above-mentioned homeless workers' movement). How is territory entwined with this experience of collective knowledge production that links academics with socioterritorial urban movements?

R. Z.: I will start off by saying that different paths have been taken. For example, Fernandes (2013) developed the idea of territories of agrarian reform confronting or disputing the idea of territories of agribusiness or monoculture. The first is a campesino territory, a family-centered economy for producing food in heterogenous territories. The latter stand in sharp contrast to the standardized territories of agribusiness that produce commodities for the market. The work of Porto Gonçalves (2001) is different. His work centers on the seringueiros of Acre, Brazil, who gather rubber in the primeval Amazonian forests. Seringueiros do not till the land and have different relationships with their territory compared to the campesinos; yet both come from the same culture, a culture which is not centered on accumulation by dispossession. And finally, there are indigenous histories, either from the lowlands - from where the concept of non-state territories has emerged - or from the highlands, that are very different, although there are crosscurrents. Indigenous peoples from the highlands, such as the Quechua, were indentured servants on the haciendas that were freed with the agrarian reforms. Indigenous peoples from the Amazon were always free, living in extensive communities in large areas based on an economy of subsistence, similar to the seringueiros. The idea of Buen Vivir ("good living") is rooted in this context, and it has been inscribed in the constitutions of Bolivia and Ecuador in the last decades. Buen Vivir involves establishing nonhierarchical, complementary relationships that are not mutually exclusive, such that humans return to a simple life with the hope of living in harmony with others, oneself, and nature. However, the notion is something declarative, something with which I agree completely, but it has no relation to reality as known in the Global North. What I am getting at is that academics reflect on different experiences but within the territory of the university. Granted, academics often have good relationships with social movements, but their reflections occur without a collective subject, and their scant participation takes an almost passive place. In any event, their ideas contribute immensely to a better understanding of peoples and their resistances, but this is never a collective production of knowledge (see also Zibechi, 2015a).

M. S. and A. S.: Current debates on practices of decolonial research call for academics to coordinate their research questions and aims with social movements, working in the interest of people affected by neoliberal urban policies. In which way could the concept of territory open up new possibilities to link specific academic interests (and requirements) with the aims of socioterritorial urban movements?

R. Z.: There are a few cases and they are very eloquent. During the 1980s, Silvia Rivera Cusicanqui created the Taller de Historia Oral Andina (THOA - Workshop on Andean Oral
History), which undertook important research in the Aymara highlands of Bolivia. One of the outcomes of her work was the creation of CONAMAQ, the Consejo Nacional de Ayllus y Markas del Qullasuyu, one of the most important indigenous community organizations in Bolivia. It led to a littleknown study that helped to reconstruct the memory of a people, supported by academics who were required to speak Aymara to join the team. Rivera Cusicanqui calls this work "collective dis-alienations" $(2008,2012)$ because the research is based on people's own memory and their own experience of oppression. By engaging with communities, they have the final word on whether they will, or will not, allow academic research to be disseminated, and in which form. In the case of THOA, the communities chose a radio soap opera in Aymara, a form of media they prefer to listen to themselves. I think that the key aspect is what kind of relationship a researcher establishes with the community. Will they continue doing extractivism, or will they reach agreements with the communities and listen to what the latter are (or are not) interested in having studied? Rivera Cusicanqui states that revealing the secrets of the oppressed is a form of betrayal, which places us in an interestingly uncomfortable place. And finally, I would like to recognize that indigenous people are already producing knowledge; they have their own intellectuals and thinkers and are increasingly able to express their ideas in an academic setting. In the future we will therefore need to pay greater attention to the work of people such as Subcomandante Insurgente Moisés, Hugo Blanco Galdós, Máxima Acuña, Luis Macas, Gladys Tzul Tzul, and others.

Data availability. No data sets were used in this article.

Competing interests. The authors declare that they have no conflict of interest.

Author contributions. The interview was jointly developed by the authors, with approximately equal shares regarding the substantial content and the workload during the writing process.

Acknowledgements. The interview was conducted in written form between December 2017 and August 2018. The text has been edited for clarity and readability. Translation by Michael Pickard. We wish to thank the Professorship of Sociology, Department of Architecture, ETH Zurich, for providing funding to translate this paper from Spanish. We would also like to thank Myriam HoussayHolzschuch and one anonymous referee for their much appreciated comments.

Review statement. This paper was edited by Myriam HoussayHolzschuch and reviewed by one anonymous referee. 


\section{References}

Fanon, F.: Peau noire, masques blancs, Paris: Les Éditions du Seuil, 1952.

Fernandes, B. M.: Territorios: teoría y disputas por el desarrollo rural, Novedades en Población, 17, 116-133, 2013.

Grosfoguel, R.: Del 'extractivismo económico' al 'extractivismo epistémico' y al 'extractivismo ontológico': Una forma destructiva de conocer, ser y estar en el mundo, Tabula Rasa, 24, 123143, 2016.

Lefebvre, H.: La production de l'espace, Paris: Éditions Anthropos, 1974.

Porto Gonçalves, C. W.: Geo-grafias. Movimientos sociales, nuevas territorialidades y sustentabilidad, Siglo XXI, México, 2001.

Rivera Cusicanqui, S.: El potencial epistemológico y teórico de la historia oral. De la lógica instrumental a la descolonización de la historia, in: Teoria crítica dos tireitos humanos no século XXI, 157-178, 2008.

Rivera Cusicanqui, S.: Ch'ixinakax utxiwa: A reflection on the practices and discourses of decolonization, S. Atl. Quart., 111, 95-109, 2012.

Svampa, M. and Viale, E.: Maldesarrollo. La Argentina del extractivismo y el despojo, Katz editores, Madrid, 2014.

Viale, E.: El extractivismo urbano, in: Extractivismo urbano. Debates para una construcción colectiva de las ciudades. Fundación Rosa Luxemburgo, edited by: Vásquez Duplat, A. M., Ceapi, El Colectivo, Buenos Aires, 2017.

Zibechi, R.: Los movimientos sociales como sujetos de la comunicación, América Latina en movimiento, available at: https: //www.alainet.org/es/active/23062, last access: 13 November 2007.
Zibechi, R.: Territorios en resistencia. Cartografía política de las periferias latinoamericanas, Lavaca, Buenos Aires, 2008.

Zibechi, R.: Dispersing Powers: Social Movements as Anti-State Forces, AK Press, Oakland, Edinburgh, Baltimore, 2010.

Zibechi, R.: Territories in Resistance. A Cartography of Latin American Social Movements, AK Press, Oakland, Edinburgh, Baltimore, 2012a.

Zibechi, R.: El movimiento de los geógrafos brasileños, La Jornada, available at: http://www.jornada.com.mx/2012/07/27/ opinion/022a1pol, last access: 27 July 2012b.

Zibechi, R.: Extractivismo en las grandes ciudades, La Jornada, available at: http://www.jornada.com.mx/2013/05/03/opinion/ 027a2pol, last access: 3 May 2013.

Zibechi, R.: Descolonizar el pensamiento crítico y las prácticas emancipatorias, Ediciones Desde Abajo, Quimantú, 2015a.

Zibechi, R.: Das Buen Vivir als die 'andere mögliche Welt': Widersprüche, Grenzen und Möglichkeiten des Konzepts im Nationalstaat, in: Lateinamerikas koloniales Gedächtnis. Vom Ende der Ressourcen, so wie wir sie kennen, edited by: Roth, J., Nomos, Baden-Baden, 69-80, 2015b.

Zibechi, R.: Movimientos sociales en América Latina. El mundo otro en movimiento, Desdeabajo, Bogotá, 2017a.

Zibechi, R.: La disputa por el territorio urbano, La Jornada, available at: http://jornada.unam.mx/2017/09/01/opinion/016a2pol, last access: 1 September 2017b. 